\title{
A Surface Morphological Study, Poly(Vinyl Chloride) Photo-Stabilizers Utilizing Ibuprofen Tin Complexes against Ultraviolet Radiation
}

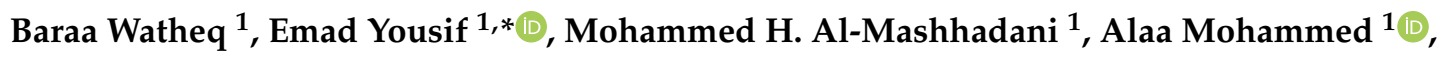 \\ Dina S. Ahmed ${ }^{2}$, Mohammed Kadhom ${ }^{3}$ and Ali H. Jawad ${ }^{4}(\mathbb{D}$ \\ 1 Department of Chemistry, College of Science, Al-Nahrain University, 64021 Baghdad, Iraq; \\ alamiribara@gmail.com (B.W.); mo_chemical@yahoo.com (M.H.A.-M.); alaaalqaycy7@gmail.com (A.M.) \\ 2 Department of Medical Instrumentation Engineering, Al-Mansour University College, 64021 Baghdad, Iraq; \\ dinasaadi86@gmail.com \\ 3 Department of Renewable Energy, College of Energy and Environmental Science, Alkarkh University of \\ Science, 64021 Baghdad, Iraq; kadhom@kus.edu.iq \\ 4 Faculty of Applied Sciences, Universiti Teknologi MARA, Shah Alam 40450, Selangor, Malaysia; \\ ali288@uitm.edu.my \\ * Correspondence: emad_yousif@hotmail.com
}

Received: 23 August 2020; Accepted: 9 October 2020; Published: 13 October 2020

\begin{abstract}
In this work, three Ibuprofen tin complexes were synthesized and characterized by Fourier Transform Infrared spectroscopy (FTIR), ${ }^{1} \mathrm{H}$ and ${ }^{119} \mathrm{Sn}-$ Nuclear Magnetic Resonance (NMR), and Energy Dispersive X-ray (EDX) spectroscopies to identify the structures. The complexes were mixed separately with poly(vinyl chloride) (PVC) to improve its photo-stability properties. Their activity was demonstrated by several approaches of the FTIR to exhibit the formation of new groups within the polymer structure due to the exposure to UV light. Moreover, the polymer's weight loss during irradiation and the average molecular weight estimation using its viscosity before and after irradiation were investigated. Furthermore, different techniques were used to study the surface morphology of the PVC before and after irradiation. Field-emission scanning electron microscopy (FESEM) and optical microscope demonstrated that applying Ibuprofen tin complexes keeps the surface of PVC smoother, with fewer cracks and spots after irradiation comparing to the blank PVC. Finally, It seems possible that such synthesized Ibuprofen tin complexes can work as excellent photo-stabilizers of PVC. In particular, complex $\mathbf{1}$ showed the best results among other stabilizers due to the large conjugation system of the stabilizer.
\end{abstract}

Keywords: morphology; PVC; tin compounds; Ibuprofen; additives; photo-stabilizers

\section{Introduction}

Many known tin (IV) complexes are related to the common prescription $\mathrm{R}_{\mathrm{x}} \mathrm{Sn}(\mathrm{L})_{4-\mathrm{x}}$, where $\mathrm{L}$ could be an inorganic or organic ligand, and $\mathrm{R}$ is an aryl or alkyl group [1]. This type of complex comprises a tin center link to the anion, typically chloride, fluoride, hydroxide, oxide, thiolate, and carboxylate [2]. In the last five decades, thousands, or maybe millions, of organometallic compounds have been synthesized, where the greater number was for organotin materials. Hence, their applications in the industry as corrosion inhibitors, plastic photo-stabilizers, medical helpers, etc., have increased $[3,4]$. The main application of the organotin derivatives (about 70\%) is as heat and light stabilizers in PVC pipes. In 1930, Germany and the United States manufactured PVC that consists of chlorinated hydrocarbon polymer. This polymer has been utilized widely around the world as one of the most important plastics because of its low cost, flame retardancy, chemical resistance, elasticity, light weight, 
good mechanical properties, electrical insulation property, and corrosion resistance [5-7]. The first discovery was in the 1940s when an organotin was used as an additive in a very small amount to PVC material to stop the photo-degradation of the plastic. Carraher et al. have prepared various plastic stabilizers depending on organotin materials [8]. Today, polyvinyl chloride is produced as the third most significant polymer after polypropylene and polyethylene [9]. This polymer is widely utilized to produce cables, pipes, disposable bottles, and some disposable kitchen stuff [10], where the main applications of PVC are pipes, doors, and window production, and secondly cables and rigid films. In 2013, PVC was produced in more than sixty million tons around the world, where China produced half of this amount [11].

However, PVC when exposed to ultraviolet gradually degrades, resulting in a decline in mechanical properties. The degradation of PVC can be seen in the discoloration, reduced ductility, and micro-cracks [12]. The low light stability of PVC will lead to a loss of $\mathrm{HCl}$ molecules in a process called discoloration, and eventually cause a severe degradation and chemical and physical alterations of the polymer properties. Various additives with low concentrations were used for the inhibition of PVC from the photo-degradation process. The most familiarly used additives are organometallics, like organotin complexes [13-15], organic [16,17], and others [18-28]. In this work, we report the synthesis of Ibuprofen tin complexes and the evaluation of their activity as photo-stabilizers for the PVC. Ibuprofen tin complexes are electron rich and could act as UV absorbers. Therefore, these complexes are expected to absorb UV irradiation and protect the PVC against photodegradation. This is quite an interesting project for the environment because it is going to reduce the consumption of plastic, which is causing a big problem for the marine eco-system.

\section{Experiment Section}

\subsection{Chemicals and Instruments}

All chemicals and solvents were purchased from Merck Company and used without further purifications. Polyvinyl chloride was obtained from Petkim Petrokimya with an average molecular weight of $\left(M_{V}=\right.$ ca. 171,000). The presence of tin in complexes was identified by using the atomic absorption flame spectrophotometer (AA-6880 Shimadzu, Kyoto, Japan). To identify the synthesized materials, the FTIR spectrophotometer ( 8300 Shimadzu, Kyoto, Japan) was utilized. Moreover, $500 \mathrm{MHz}$ ${ }^{1} \mathrm{H}$ NMR using tetramethylsilane as the internal standard in deuterated dimethyl sulfoxide was applied to identify the chemical shifts of protons within the structure of the synthesized specimens. Varian INOVA spectrometer (Lake Forest, CA, USA) was utilized to record this data; furthermore, a Bruker DRX spectrophotometer was used for characterization, ${ }^{119}$ Sn NMR (107 MHz). The PVC films were exposed to UV light utilizing an accelerated weather meter provided from Q-Panel Company. All NMR samples were prepared by dissolving $15 \mathrm{mg}$ of the substance in $2 \mathrm{~mL}$ of the Dimethyl sulfoxide (DMSO) at room temperature. The sample was shaken or ultrasonic was used if necessary until full dissolving was achieved. $500 \mathrm{MHz} 1 \mathrm{H}$ NMR and $107 \mathrm{MHz}$ 119Sn NMR was used to identify the substance with 16 scans. The samples were irradiated at room temperature with a maximum wavelength of $365 \mathrm{~nm}$. Moreover, the polymer molecular weight was estimated by measuring the viscosity of the polymer using the Ostwald U-Tube Viscometer technique. TESCAN MIRA3 LMU EDS was used to investigate the morphology of the PVC film surface utilizing $10 \mathrm{kV}$ as an accelerating voltage.

\subsection{Synthesis of $P h_{3} S n L$ Complex (1)}

A suitable amount of Ibuprofen $(0.206 \mathrm{~g} ; 1.0 \mathrm{mmol})$ was mixed with $(0.385 \mathrm{~g} ; 1.0 \mathrm{mmol})$ of triphenyltin chloride and left to stir for $6 \mathrm{~h}$ in boiling methanol (MeOH; $30 \mathrm{~mL})$. Then the mixture was cooled down to room temperature and filtered to get the crude product, which was washed with methanol to obtain the desired compound (complex $\mathbf{1}$ ). 


\subsection{Synthesis of $B u_{2} S n L_{2}$ Complex (2)}

A suitable amount of Ibuprofen $(0.412 \mathrm{~g} ; 2.0 \mathrm{mmol})$ was mixed with $(0.303 \mathrm{~g} ; 1.0 \mathrm{mmol})$ of dibutyltin chloride and left to stir for $8 \mathrm{~h}$ in boiling methanol (MeOH; $30 \mathrm{~mL})$. After that, the mixture was cooled down to ambient temperature and filtered to give the crude product, which was washed with methanol to obtain the desired compound (complex 2).

\subsection{Synthesis of $\mathrm{Bu}_{2} \mathrm{SnOHL}$ Complex (3)}

A suitable amount of Ibuprofen $(0.206 \mathrm{~g} ; 1.0 \mathrm{mmol})$ was mixed with $(0.248 \mathrm{~g} ; 1.0 \mathrm{mmol})$ of dibutyltin oxide and left to stir for $6 \mathrm{~h}$ in boiling methanol (MeOH; $30 \mathrm{~mL}$ ). Later, the mixture was cooled down to room temperature and filtered to give the crude product, which was washed with methanol to produce complex 3 .

\subsection{Preparation of PVC Films}

PVC (5.0 g) in tetrahydrofuran (THF; $100 \mathrm{~mL}$ ) was stirred at room temperature for two hours with $0.5 \mathrm{wt}$ \% of the complexes to get a homogenous mixture. After that, it was poured into the glass plates to form homogenous films with a thickness of $40 \mu \mathrm{m}$. All prepared films were dried using a vacuum to remove the trace amount of solvent that could affect the measurements.

\subsection{Utilizing the FTIR Technique to Investigate the Photo-Degradation of PVC}

FTIR technique was also used to examine the photo-degradation of polymer films through following the formation and growth of carbonyl $\mathrm{C}=\mathrm{O}$ and alkene $\mathrm{C}=\mathrm{C}$ groups $[29,30]$. The functional group index $\left(I_{S}\right)$ for both groups $\mathrm{C}=\mathrm{O}$ and $\mathrm{C}=\mathrm{C}$ was determined using the flowing equation [31].

$$
I_{S}=A_{s} / A_{r}
$$

where $A_{S}$ is the functional group absorbance and $A_{r}$ is the standard peak absorbance.

\subsection{Utilizing the Weight Loss Technique to Investigate the Photo-Degradation of PVC}

The photo-stability of PVC was also examined by calculating the weight loss of the polymer during irradiation time in the existence of the stabilizers. Hence, weight loss was calculated according to Equation (2).

$$
\text { Weight loss }(\%)=\left[\left(W_{0}-W_{t}\right) / W_{0}\right] \times 100
$$

where $W_{0}$ is the weight of PVC before irradiation and $W_{t}$ is the weight after irradiation [32].

\subsection{Calculation of the Average Molecular Weight $\left(\bar{M}_{V}\right)$ of PVC}

The intrinsic viscosity $[\eta]$ of the polymer solution was measured, and the $\bar{M}_{V}$. of PVC after irradiation was measured according to Equation (3). This equation is called the Mark-Houwink equation [33].

$$
[\eta]=1.63 \times 10^{-2} M_{v}^{0.766}
$$

\section{Results and Discussion}

\subsection{Characterization of Synthesized Complexes}

Three organotin(IV) complexes $\mathrm{Bu}_{2} \mathrm{SnL}_{2}, \mathrm{Ph}_{3} \mathrm{SnL}$, and $\mathrm{Bu}_{2} \mathrm{SnOHL}$ were prepared by reacting di- and tri-organotin chlorides and di-organotin oxide with Ibuprofen as a ligand (L) under reflux conditions for 6-8 h in the presence of methanol as solvent (Schemes 1-3). Elemental analysis was used to clarify the elemental composition of the three prepared complexes and check the purity of them. 
The high purity of Ibuprofen tin complexes made the complexes more stable. All data are presented in Table 1.<smiles>CC(C)Cc1ccc(C(C)C(=O)O)cc1</smiles>

Scheme 1. Preparation of complex 1.<smiles>CC(C)Cc1ccc(C(C)C(=O)OC(C)(C)C(=O)OC(C)(C)C(=O)OC(C)(C)C(C)c2ccc(CC(C)C)cc2)cc1</smiles>

Scheme 2. Preparation of complex 2.

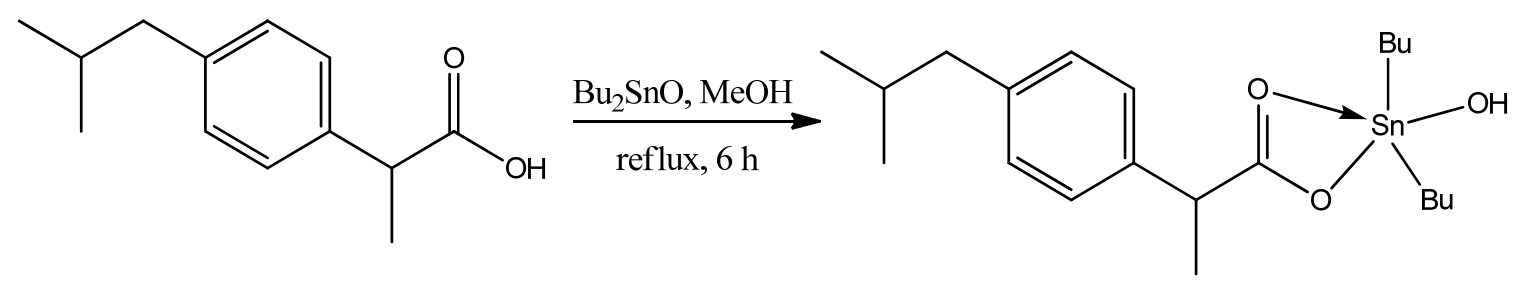

Scheme 3. Preparation of complex 3.

Table 1. Elemental analysis and physical properties of synthesized complexes.

\begin{tabular}{|c|c|c|c|c|c|c|c|}
\hline \multirow{2}{*}{ Complex } & \multirow{2}{*}{ Code } & \multirow{2}{*}{ Colour } & \multirow{2}{*}{ Melting Point $\left({ }^{\circ} \mathrm{C}\right)$} & \multirow{2}{*}{ Yield (\%) } & \multicolumn{3}{|c|}{ Found (Calculated) (\%) } \\
\hline & & & & & C & $\mathbf{H}$ & Sn \\
\hline Ibuprofen & L & white & $75-78$ & - & $(75.69)$ & $(8.80)$ & - \\
\hline $\mathrm{Ph}_{3} \mathrm{SnL}$ & 1 & white & $210-212$ & 97 & $\begin{array}{c}66.98 \\
(67.05)\end{array}$ & $\begin{array}{c}5.75 \\
(5.81)\end{array}$ & $\begin{array}{c}21.25 \\
(21.38)\end{array}$ \\
\hline $\mathrm{Bu}_{2} \mathrm{SnL}_{2}$ & 2 & white & 190-192 & 72 & $\begin{array}{c}63.47 \\
(63.46)\end{array}$ & $\begin{array}{c}8.20 \\
(8.15)\end{array}$ & $\begin{array}{c}18.47 \\
(18.45)\end{array}$ \\
\hline $\mathrm{Bu}_{2} \mathrm{SnOHL}$ & 3 & white & $233-235$ & 92 & $\begin{array}{c}55.35 \\
(55.41)\end{array}$ & $\begin{array}{c}7.88 \\
(7.97)\end{array}$ & $\begin{array}{c}26.01 \\
(26.08)\end{array}$ \\
\hline
\end{tabular}

The FTIR spectrum for Ibuprofen was compared with the spectra of organotin(IV) complexes to clarify the bonding sites of ligand molecules when coordinated with organotin(IV) compounds. All FTIR data of the prepared complexes and free ligands were summarized in Table 2. The presence of a broad peak in the FTIR spectrum of the ligand (Ibuprofen) at the region between 3000 and $3300 \mathrm{~cm}^{-1}$ was demonstrated. This peak is related to the stretching of the $\mathrm{O}-\mathrm{H}$ bond of the carboxylic group. Thus, the peak disappeared in the ligand-tin complexes FTIR spectrum; this is clear evidence that the complexation has successfully happened after the deprotonation of the carboxylic group. The peak of carbonyl group $v(\mathrm{C}=\mathrm{O})$ appeared at $1720 \mathrm{~cm}^{-1}$ and was shifted in the complexes toward lower frequency. The diagnostic bands for the carboxylate anti-symmetric $\left[v_{\text {as }}(\mathrm{COO})\right]$ are observed at $1627-1716$, while the symmetric $[v(\mathrm{COO})]$ are observed at $1404-1423 \mathrm{~cm}^{-1}$ for stretching vibrations of complexes due to the complex formation. Calculating the change between $v_{\text {asy }}(\mathrm{COO})$ and $v_{\text {sy }}(\mathrm{COO})$ $(v)$ evaluates the possible mode of coordination of carboxylates to tin metal. The $\Delta v(\mathrm{COO})$ values were obtained by the following equation $\left[\Delta v(\mathrm{COO})=v_{\text {asym }}(\mathrm{COO})-v_{\text {sym }}(\mathrm{COO})\right]$ and the result showed that $\Delta v(\mathrm{COO})$ is $>200 \mathrm{~cm}^{-1}$. In this case, the Ibuprofen is considered as an asymmetric bidentate ligand [34]. 
Table 2. Ligand and complexes FTIR spectra data.

\begin{tabular}{ccccccc}
\hline Compounds & $\mathbf{v}_{\mathbf{s}}(\mathbf{O H})$ & $\mathbf{v}_{\text {as }}(\mathbf{C O O})$ & $\mathbf{v}_{\mathbf{s}}(\mathbf{C O O})$ & $\boldsymbol{\Delta} \mathbf{v}(\mathbf{C O O})$ & $\boldsymbol{v}(\mathbf{S n}-\mathrm{C})$ & $\boldsymbol{v}(\mathbf{S n}-\mathbf{O})$ \\
\hline $\mathrm{L}$ & 3300 & 1720 & 1419 & 301 & $-\overline{1}$ & - \\
$\mathrm{Ph}_{3} \mathrm{SnL}$ & - & 1716 & 1423 & 293 & 551 & 443 \\
$\mathrm{Bu}_{2} \mathrm{SnL}$ & - & 1716 & 1419 & 297 & 555 & 482 \\
$\mathrm{Bu}_{2} \mathrm{SnOL}$ & - & 1627 & 1404 & 223 & 543 & 478 \\
\hline
\end{tabular}

Furthermore, the presence of peaks was demonstrated between 443 and $482 \mathrm{~cm}^{-1}$, and 543 and $555 \mathrm{~cm}^{-1}$, which are related to stretching $\mathrm{Sn}-\mathrm{O}$ bond frequency, and stretching $\mathrm{Sn}-\mathrm{C}$ bond frequency, respectively. This is obvious evidence regarding the complex formation [35].

The ligand and organotin(IV) complexes were also characterized by ${ }^{1} \mathrm{H}$ - and ${ }^{119} \mathrm{Sn}$-nuclear magnetic resonance (NMR) in DMSO-d. The main signals of the chemical shift are listed in Table 3. ${ }^{1} \mathrm{H}$ NMR spectra showed all needed peaks to demonstrate the chemical structure of the ligand and complexes $(\mathbf{1}, \mathbf{2}, \mathbf{3})$. As can be seen from Table 3, the chemical shifts of ligands shifted up and down filed when linked to $\mathrm{Sn}$ metal. These alternations in ${ }^{1} \mathrm{H}$ NMR chemical shift between the complexes and ligand are due to the different environments around the protons. A single peak in the ${ }^{1} \mathrm{H}-\mathrm{NMR}$ spectrum at $12.27 \mathrm{ppm}$ of the ligand is observed, which is related to the proton of the carboxylic group. Hence, this peak disappeared in the ${ }^{1} \mathrm{H}-\mathrm{NMR}$ spectra of the complex due to the deprotonation of the carboxylic group after the complexation occurred. This indicates the bonding and coordination between ligand and complexes. The signal at $3.6 \mathrm{ppm}$ corresponds to the HDO proton [36]. The ${ }^{119} \mathrm{Sn}$-NMR spectra were verified in the DMSO- $d_{6}$ solvent for the three complexes. Di-organotin(IV) complexes give a resonance at -255.2 and $-226.2 \mathrm{ppm}$, which are attributed to the 2 and $\mathbf{3}$ complexes, respectively. This fits within the range of six coordinated complexes. In the case of complex $\mathbf{1}$, the resonance of the ${ }^{119} \mathrm{Sn}$ was at $-171.4 \mathrm{ppm}$, which indicates the Penta-coordinate of the complex [37]. The ${ }^{119} \mathrm{Sn}$ NMR, ${ }^{1} \mathrm{H}$ NMR, and FTIR spectra for the Ibuprofen and complexes were illustrated in the Supplementary Materials.

Table 3. ${ }^{1} \mathrm{H}$ and ${ }^{119} \mathrm{Sn}$ NMR spectral data for tin complexes.

\begin{tabular}{|c|c|c|}
\hline \multirow{2}{*}{ Compound } & \multicolumn{2}{|c|}{ NMR (DMSO- $d_{6}$ ) Chemical Shifts ppm } \\
\hline & ${ }^{1} \mathrm{H}(500 \mathrm{MHz})$ & ${ }^{119} \mathrm{Sn}(107 \mathrm{MHz})$ \\
\hline $\mathbf{L}$ & $\begin{array}{c}12.27(\mathrm{~s}, 1 \mathrm{H}, \mathrm{COOH}), 7.20(\mathrm{~d}, J=8.0,2 \mathrm{H}, \mathrm{CH} \text { aromatic } \\
\text { ring), } 7.10(\mathrm{~d}, J=7.6,2 \mathrm{H}, \mathrm{CH} \text { aromatic ring }), 3.46(\mathrm{q}, 1 \mathrm{H}, \\
\mathrm{CH}), 2.41\left(\mathrm{~d}, J=8.0,2 \mathrm{H}, \mathrm{CH}_{2}\right), 1.82(\mathrm{~m}, 1 \mathrm{H}, \mathrm{CH}), 1.78(\mathrm{~d}, \\
\left.3 \mathrm{H}, \mathrm{CH}_{3}\right), 0.86\left(\mathrm{~d}, 6 \mathrm{H}, 2 \mathrm{CH}_{3}\right) .\end{array}$ & - \\
\hline 1 & $\begin{array}{c}\text { 8.01-7.66 (br m, } 15 \mathrm{H}, \mathrm{CH} \text { aromatic ring), } 7.21-7.48(\mathrm{~m}, 4 \mathrm{H} \text {, } \\
\mathrm{CH} \text { aromatic ring), } 3.77(\mathrm{q}, 1 \mathrm{H}, \mathrm{CH}), 2.43\left(\mathrm{~d}, 2 \mathrm{H}, \mathrm{CH}_{2}\right) \\
1.84(\mathrm{~m}, 1 \mathrm{H}, \mathrm{CH}), 1.75\left(\mathrm{~d}, 3 \mathrm{H}, \mathrm{CH}_{3}\right), 0.88\left(\mathrm{~d}, 6 \mathrm{H}, 2 \mathrm{CH}_{3}\right) \\
7.08-7.19(\mathrm{~d}, 8 \mathrm{H}, \mathrm{CH} \text { aromatic ring }), 3.64(\mathrm{~d}, 2 \mathrm{H}, 2 \mathrm{CH})\end{array}$ & -171.4 \\
\hline 2 & $\begin{array}{c}2.42\left(\mathrm{~d}, 4 \mathrm{H}, 2 \mathrm{CH}_{2}\right), 1.83(\mathrm{~m}, 2 \mathrm{H}, 2 \mathrm{CH}), 1.77\left(\mathrm{~d}, 2 \mathrm{CH}_{3}, 6 \mathrm{H}\right) \\
1.33-1.63(\mathrm{~m}, \mathrm{propyl} \text { of dibut, } 12 \mathrm{H}), 0.82-0.86 \\
\left(\mathrm{~m}, 18 \mathrm{H}, 6 \mathrm{CH}_{3}\right) .\end{array}$ & -255.2 \\
\hline 3 & $\begin{array}{c}6.85-7.17(\mathrm{~d}, 4 \mathrm{H}, \mathrm{CH} \text { aromatic ring }), 3.74(\mathrm{q}, 1 \mathrm{H}, \mathrm{CH}) \\
2.46\left(\mathrm{~d}, 2 \mathrm{H}, \mathrm{CH}_{2}\right), 2.08(\mathrm{~s}, \mathrm{OH}), 1.78(\mathrm{~m}, 1 \mathrm{H}, \mathrm{CH}), 1.46(\mathrm{~d}, \\
\left.3 \mathrm{H}, \mathrm{CH}_{3}\right), 1.23-1.37(\mathrm{~m}, \text { propyl of dibut } 12 \mathrm{H}), 0.85-0.98 \\
\left(\mathrm{~m}, 4 \mathrm{CH}_{3}, 12 \mathrm{H}\right) .\end{array}$ & -226.2 \\
\hline
\end{tabular}

\subsection{Utilizing FTIR Technique to Examine the Photo-Stability of PVC Films}

The efficiency of the organotin(IV) complexes as light stabilizer of PVC was examined using the FTIR technique. The Irradiated PVC films with ultraviolet light at a maximum wavelength of 365 $\mathrm{nm}$ for $300 \mathrm{~h}$ caused an alteration in the FTIR spectrum. Three absorption peaks appeared in the infrared spectra of the PVC films after exposure to UV light. This could be attributed to the formation 
of hydroxyl $3500 \mathrm{~cm}^{-1}(\mathrm{OH})$, carbonyl $1722 \mathrm{~cm}^{-1}(\mathrm{C}=\mathrm{O})$, and polyene $1604 \mathrm{~cm}^{-1}(\mathrm{C}=\mathrm{C})$ groups [38]. As shown in Figure 1, a growth of three signals can be detected in the blank PVC after exposure to UV light for a long time, while the polymer with additives showed higher stability, and complex $\mathbf{1}$ was the most effective stabilizer. These three peaks are hydroxyl $(\mathrm{OH})$ at $3500 \mathrm{~cm}^{-1}$, carbonyl $(\mathrm{C}=\mathrm{O})$ at $1722 \mathrm{~cm}^{-1}$, and polyene $(\mathrm{C}=\mathrm{C})$ at $1604 \mathrm{~cm}^{-1}$ groups. The growth rate of these peaks is related to the reference peak $\left(1328 \mathrm{~cm}^{-1}\right)$, which can be considered as a measure of the photo-degradation of PVC according to Equation (1) to determine $I_{\mathrm{C}=\mathrm{O}}$ and $I_{\mathrm{C}=\mathrm{C}}$ indices. They are plotted against irradiation time for the blank PCV and PVC + complexes using an interval time of 50-300 h of irradiation in Figures 2 and 3, respectively. Thereby, it has been demonstrated that both indices exhibit a significant reduction for $I_{\mathrm{C}=\mathrm{O}}$ and $I_{\mathrm{C}=\mathrm{C}}$ in the existence of additives with PVC compared to blank PVC. For instance, the $I_{\mathrm{C}=\mathrm{O}}$ values after $300 \mathrm{~h}$ of exposure to UV light were $0.599,0.542,0.413$, and 0.287 for the PVC, PVC +3 , $\mathrm{PVC}+2$, and $\mathrm{PVC}+1$, respectively. Thus, with common qualities, the $I_{\mathrm{C}=\mathrm{C}}$ values decreased in the presence of additives as follows: 0.394, 0.334, 0.298, and 0.231 for PVC, PVC + 3, PVC + 2, and PVC +1 , respectively, after irradiation $(300 \mathrm{~h})$. Here, it can be concluded that all three stabilizers work to protect the PVC from photo-degradation and the best one is complex 1 . This could be explained as complex $\mathbf{1}$ is linked to Ibuprofen and three phenyl groups that absorb within the UV region because of their conjugation system.

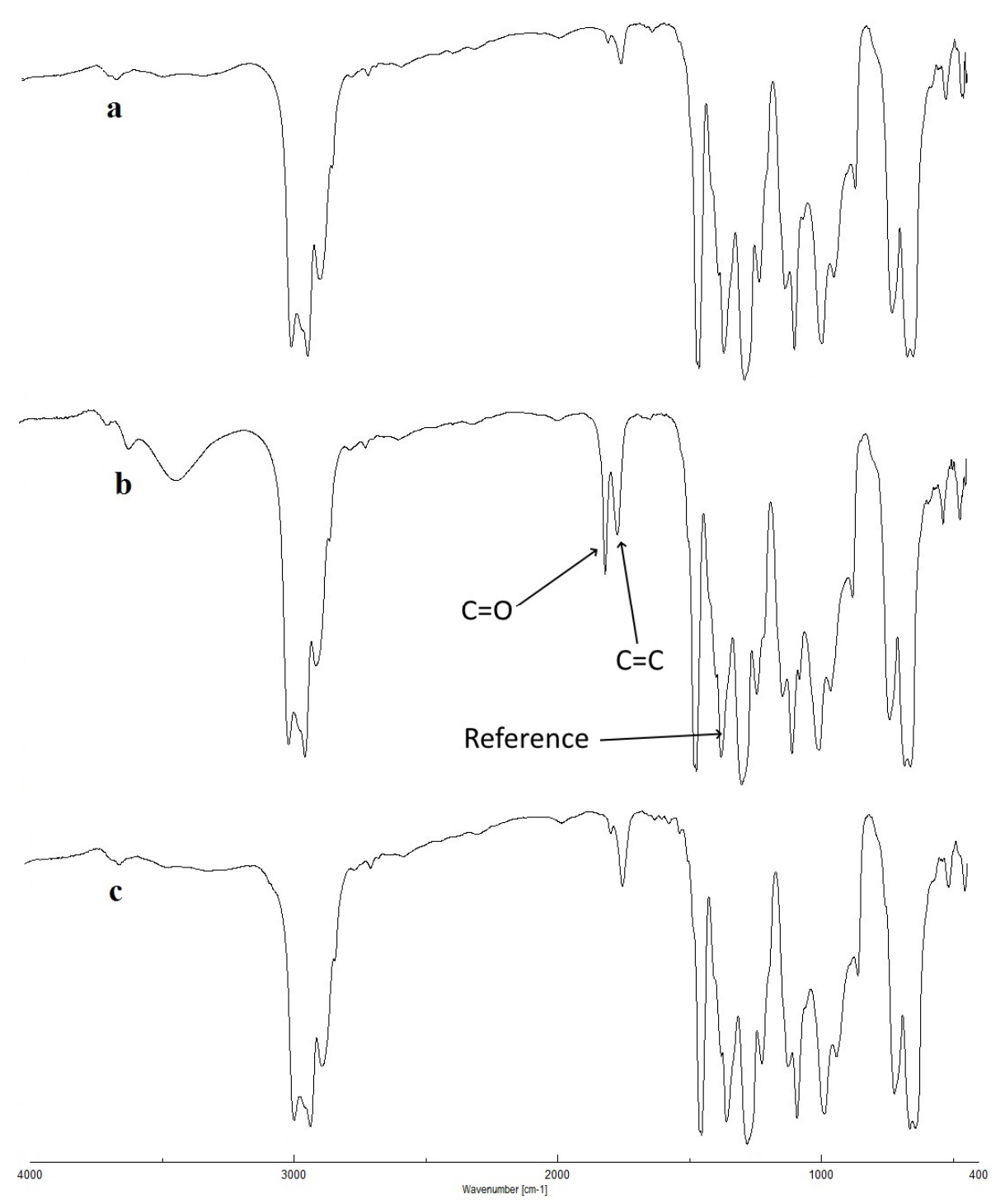

Figure 1. FTIR spectra of (a) blank poly(vinyl chloride) (PVC) before irradiation, (b) blank PVC after irradiation (300 h), and (c) PVC +1 blend after irradiation (300 h). 


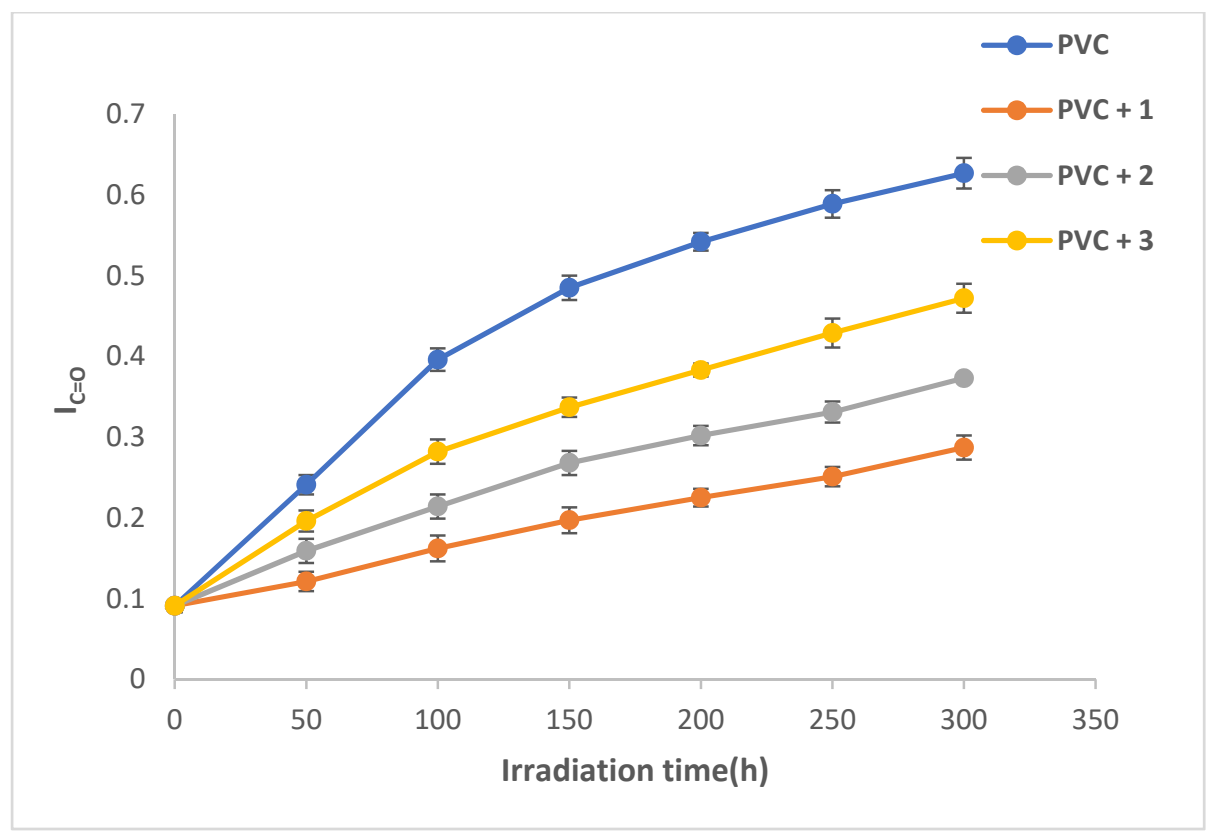

Figure 2. Irradiation time against $I_{\mathrm{C}=\mathrm{O}}$ index alternations of PVC.

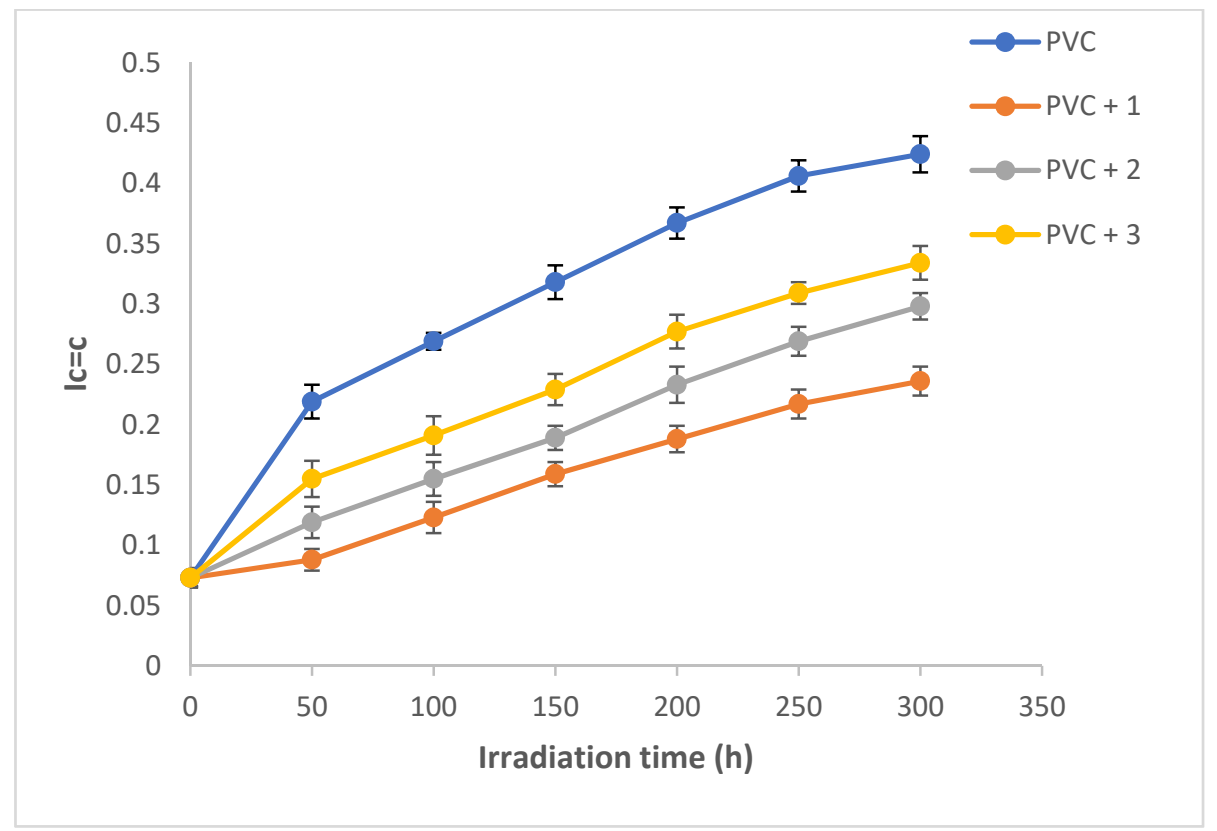

Figure 3. Irradiation time against $I_{\mathrm{C}=\mathrm{C}}$ index alternations of PVC.

\subsection{Utilizing Weight Loss to Examine the Photo-Stability of PVC Films}

Photo-degradation of PVC leads to dehydro-chlorination, and small organic residue elimination resulting in weight loss [39]. The weight loss of PVC was measured at $50 \mathrm{~h}$ intervals of irradiation using Equation (2). Figure 4 illustrates the alterations to the percentage of PVC weight loss at different irradiation times up to $300 \mathrm{~h}$. Clearly, the PVC films containing complexes of organotin display a lower weight loss relative to that obtained for blank PVC.

Weight loss investigation is in agreement with the functional group indices effect since it shows that complex 1 demonstrated the best photo-stability against PVC photo-degradation. As mentioned above, this is due to the large aromatic conjugation system which is available in complex $\mathbf{1}$. 


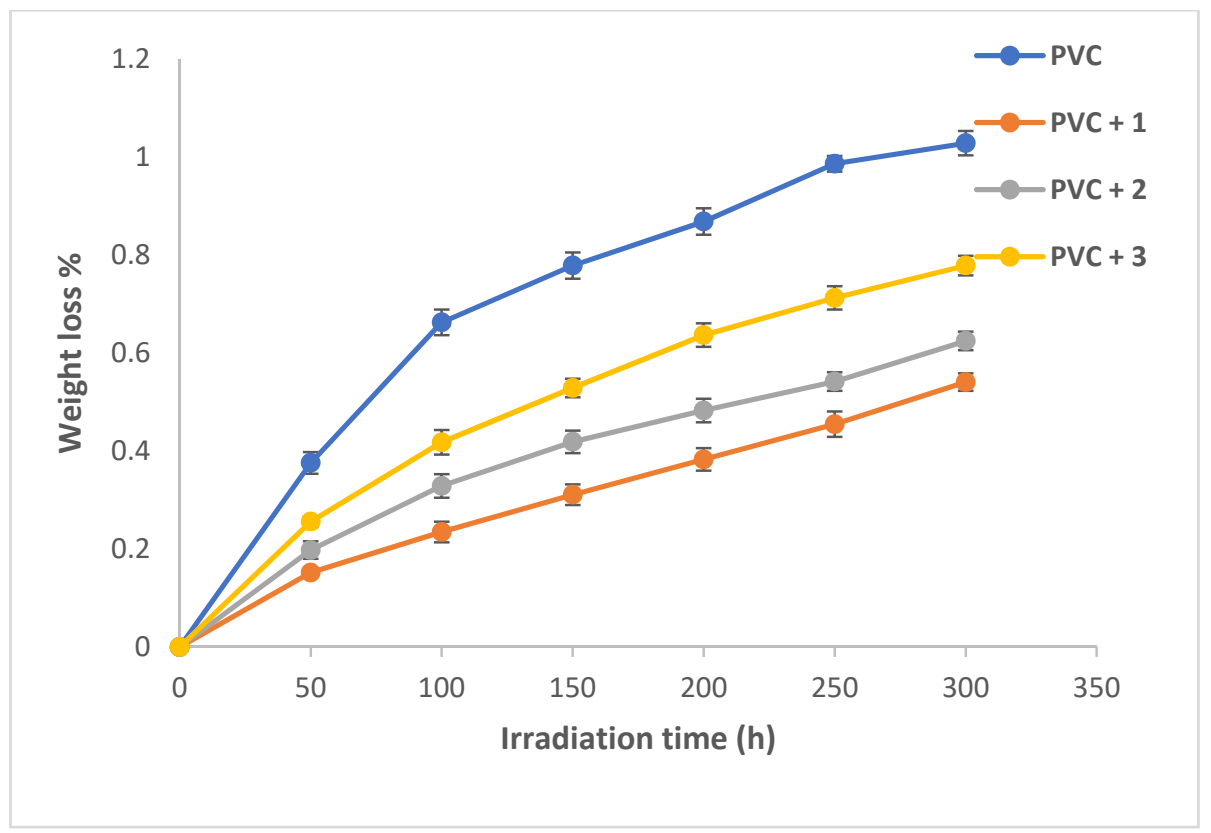

Figure 4. Weight loss of PVC films with irradiation time.

\subsection{Calculation of the Average Molecular Weight $\left(\bar{M}_{V}\right)$ by Utilizing Viscosity}

An estimate the average molecular weight of the polymer was obtained using viscosity. Hence, the degradation causes the breaking of the polymer chain, which leads to decreasing the polymer's molecular weight [40]. The PVC solution viscosity is used to measure the $\bar{M}_{V}$. The irradiated PVC films were dissolved in the THF and the viscosity was measured using a viscometer [33]. The $\bar{M}_{V}$. for each film at different irradiation times was calculated using Equation (3). Figure 5 shows the $\bar{M}_{V}$. against irradiation time for the blank and additive-filled PVC. The $\bar{M}_{V}$ of PVC film was reduced dramatically during the irradiation process. As a result, the $\bar{M}_{V}$ for blank PVC film was approximately 170,100 at the beginning and decreased to 12,700 after $300 \mathrm{~h}$ of irradiation, while the $\bar{M}_{V}$. of PVC $+3, \mathrm{PVC}+$ 2, and PVC + 1 were 26,200, 35,400, and 44,600 at same conditions. Obviously, this study is in good agreement with the functional groups and weight loss studies. PVC $+\mathbf{1}$ has the highest $\bar{M}_{V}$ among other stabilizers, which means $\mathrm{Ph}_{3} \mathrm{SnL}(\mathbf{1})$ is the best photo-stabilizer of PVC against photo-degradation.

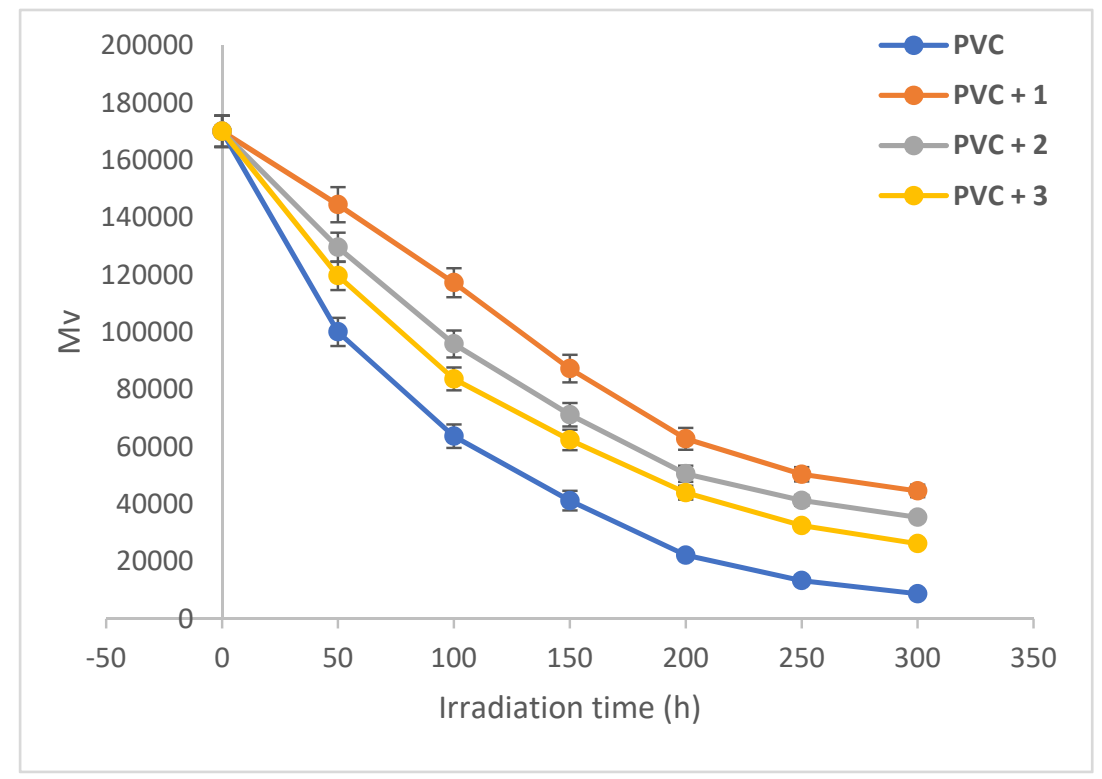

Figure 5. $\bar{M}_{V}$ of PVC against irradiation time. 


\subsection{Utilizing Energy Dispersive X-ray (EDX) to Examine the Photo-Stability of PVC Films}

The energy dispersive X-ray (EDX) technique was utilized to analyze the elemental composition of PVC films with tin complexes after and before irradiation. Figure 6 shows the elements and EDX images of PVC films [41] that demonstrated the additives were well mixed with the polymer materials [42]. The percentage of chlorine in blank PVC is $57.9 \%$ after $300 \mathrm{~h}$ irradiation due to the release of hydrogen chloride molecules during irradiation. It was demonstrated that releasing of $\mathrm{HCl}$ for blank PVC is much higher than polymer mixes with stabilizers.
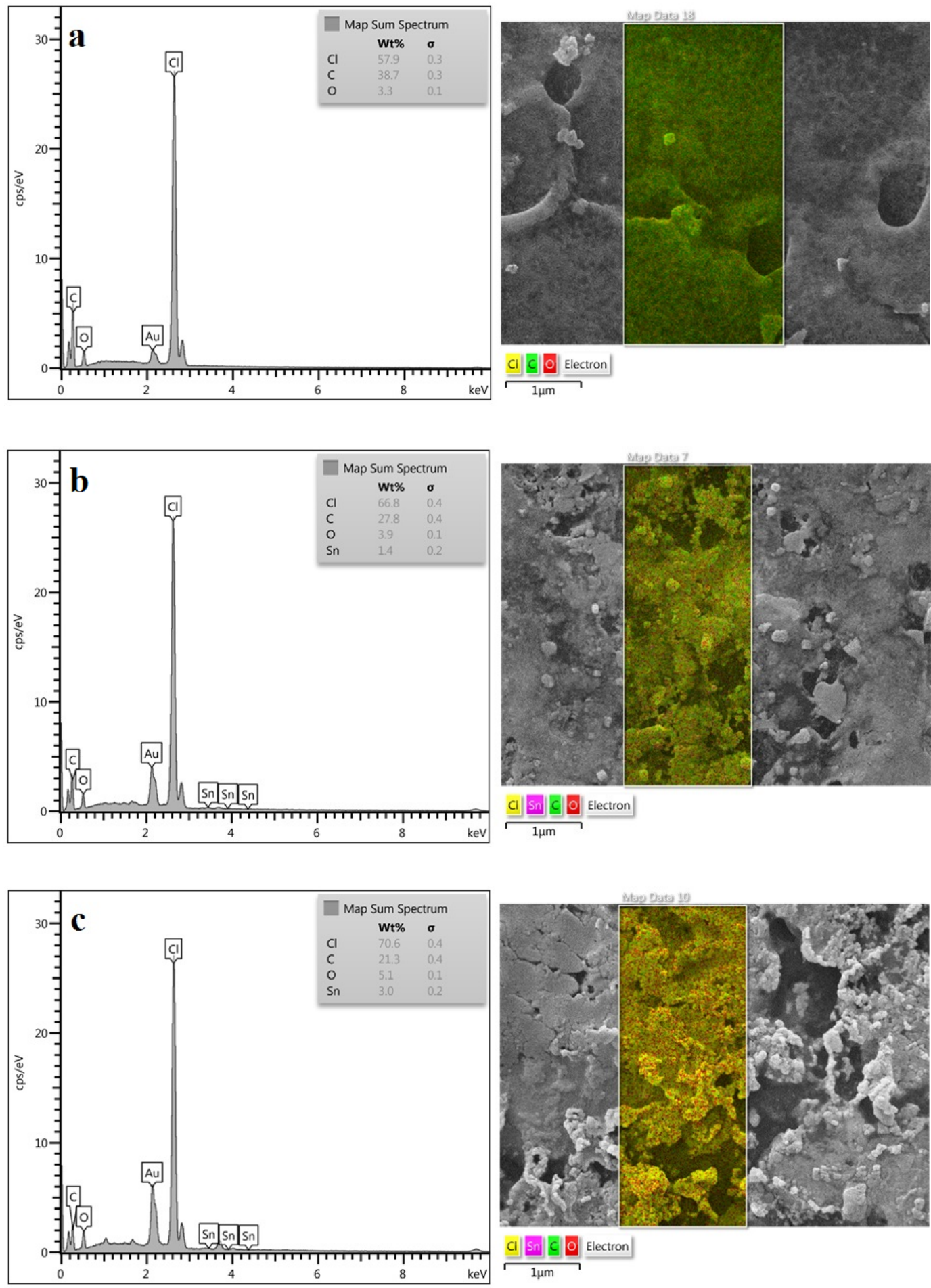

Figure 6. Cont. 

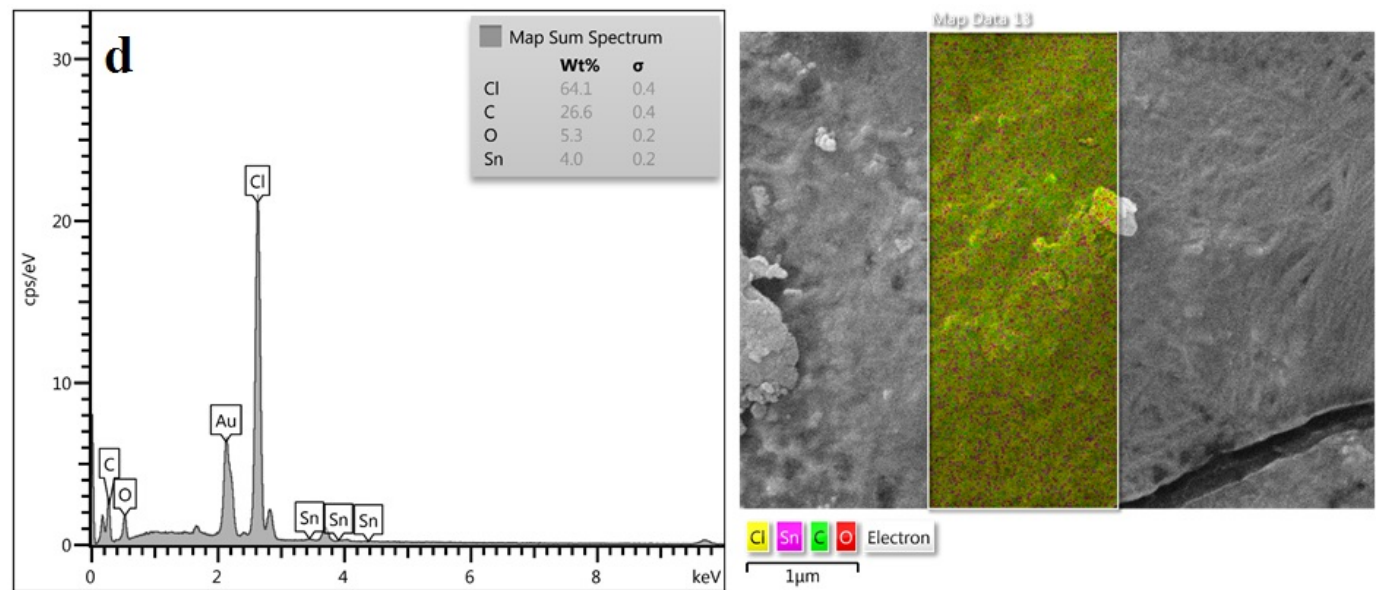

Figure 6. EDX mapping graphs of (a) PVC (b) PVC $+\mathbf{1}$ (c) PVC $+\mathbf{2}$ and (d) PVC $+\mathbf{3}$ after exposure to UV light.

\subsection{Morphological Analysis of PVC Films}

The morphology of the PVC surface was examined utilizing FESEM and microscope techniques. The FESEM images of the PVC surface (as shown in Figure 7) exhibited homogenous and smooth blank PVC surface before irradiation [43]. Figure 8 shows the FESEM images of blank PVC and PVC + additives after exposure to UV light. Thus, it has been demonstrated from Figure 8a that PVC surface without additives and after irradiation shows big cracks and roughness which was attributed to the breaking of polymer chains into small fragments. Another reason could be that the polymer undergoes an elimination reaction and releases $\mathrm{HCl}$ molecules to form alkene groups [44]. However, Figure 8b-d shows the FESEM images of the PVC films mixed with tin complexes after exposure to UV light. The PVC containing complexes' surface was smoother and had fewer cracks compared to the blank PVC after irradiation. Figure 9 shows images of the modified PVC surfaces under the microscope before and after exposure to UV light.

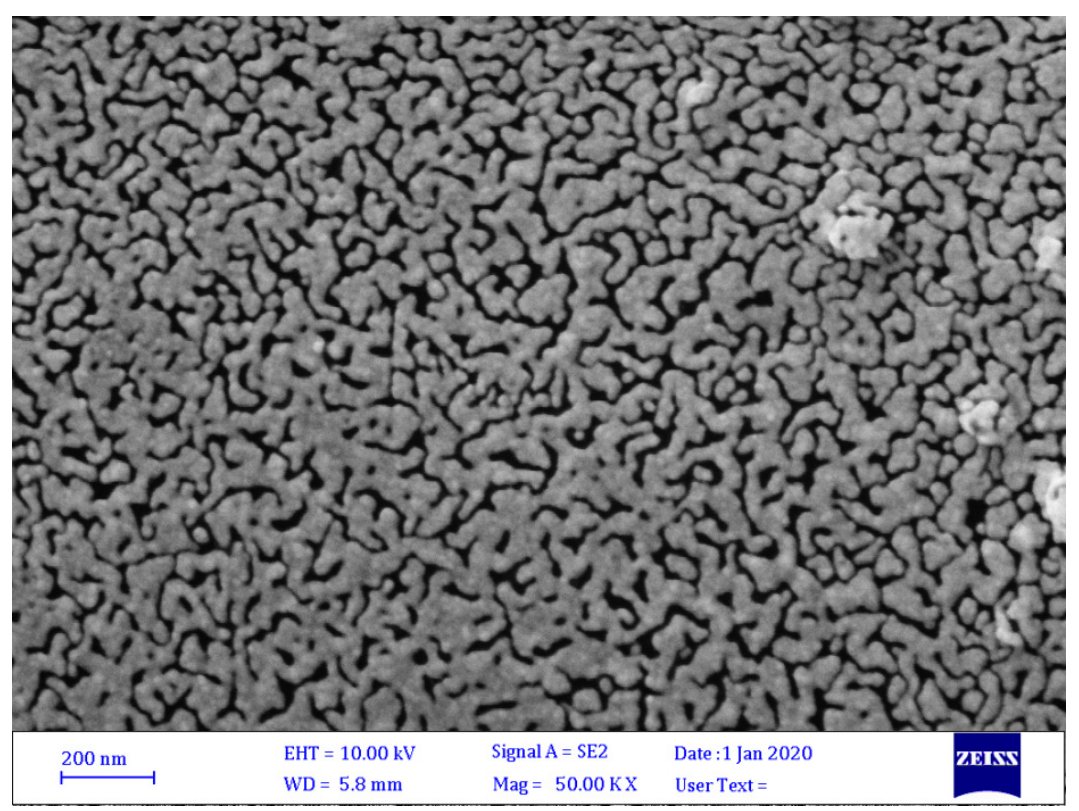

Figure 7. Field-emission scanning electron microscopy (FESEM), blank PVC images before exposure to UV light. 

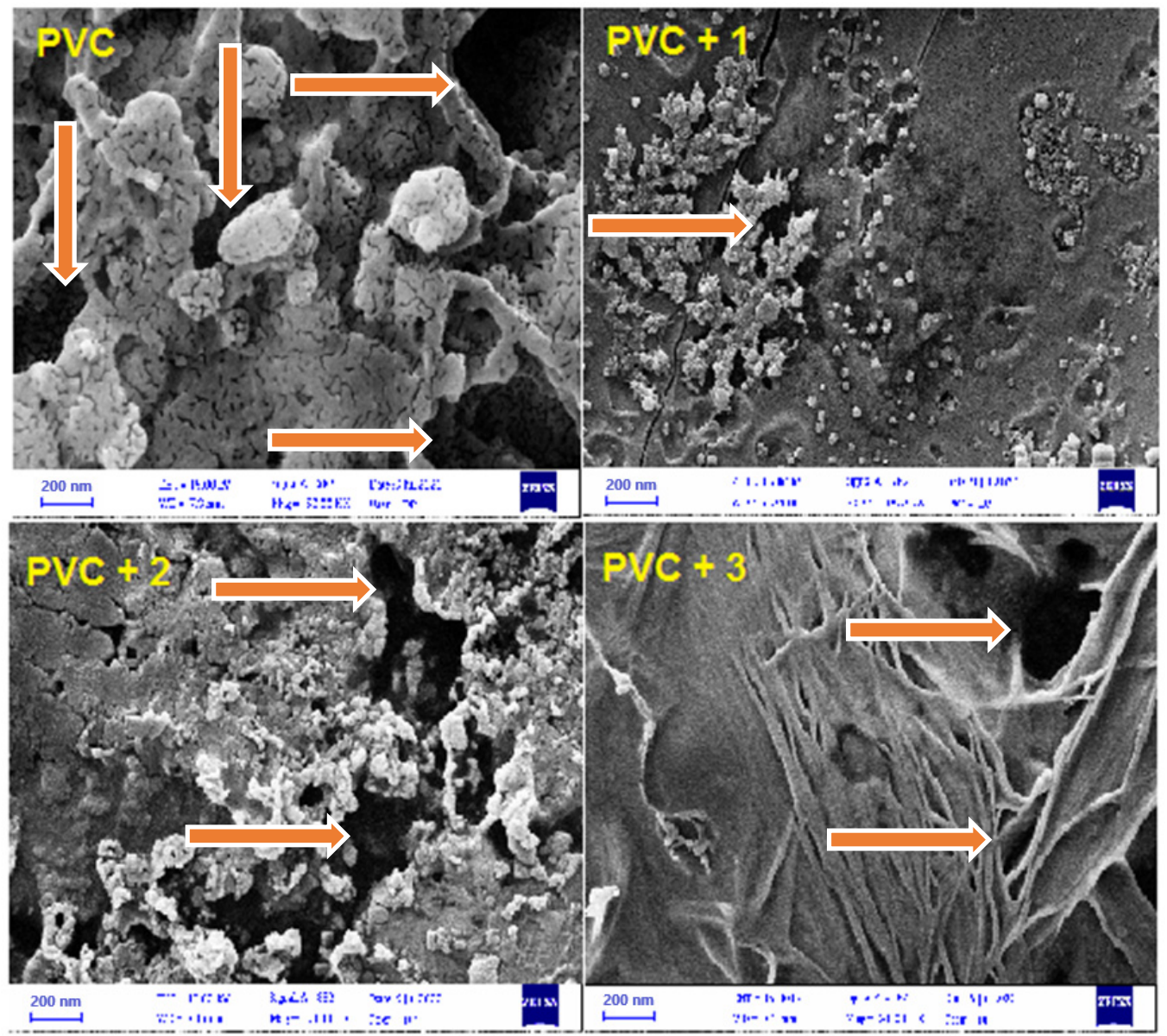

Figure 8. FESEM PVC surface images. (a) PVC, (b) PVC $+\mathbf{1}$, (c) PVC $+\mathbf{2}$, and (d) PVC +3 after $300 \mathrm{~h}$ of UV light exposure at intensity of $6.43 \times 10^{-9} \mathrm{ein} \cdot \mathrm{dm}^{-3} \cdot \mathrm{s}^{-1}$. All images' scale is $200 \mathrm{~nm}$.

(a)

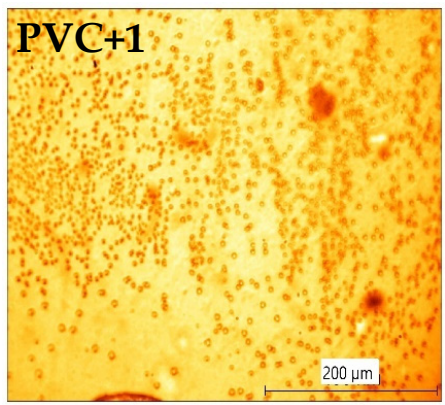

(b)

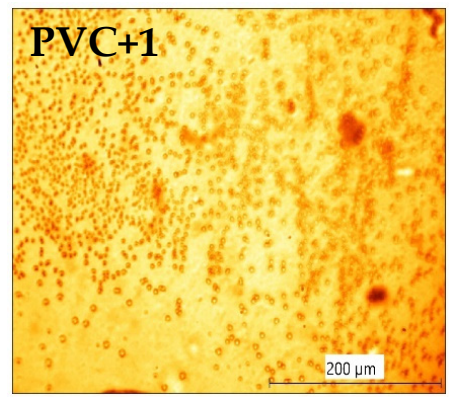

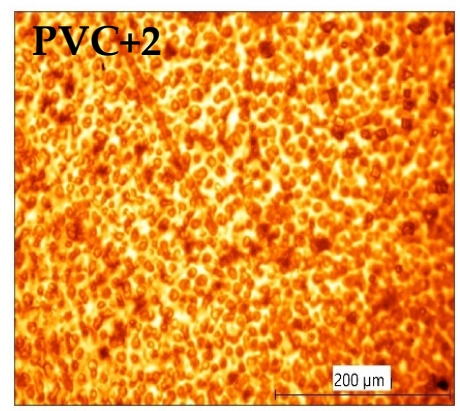
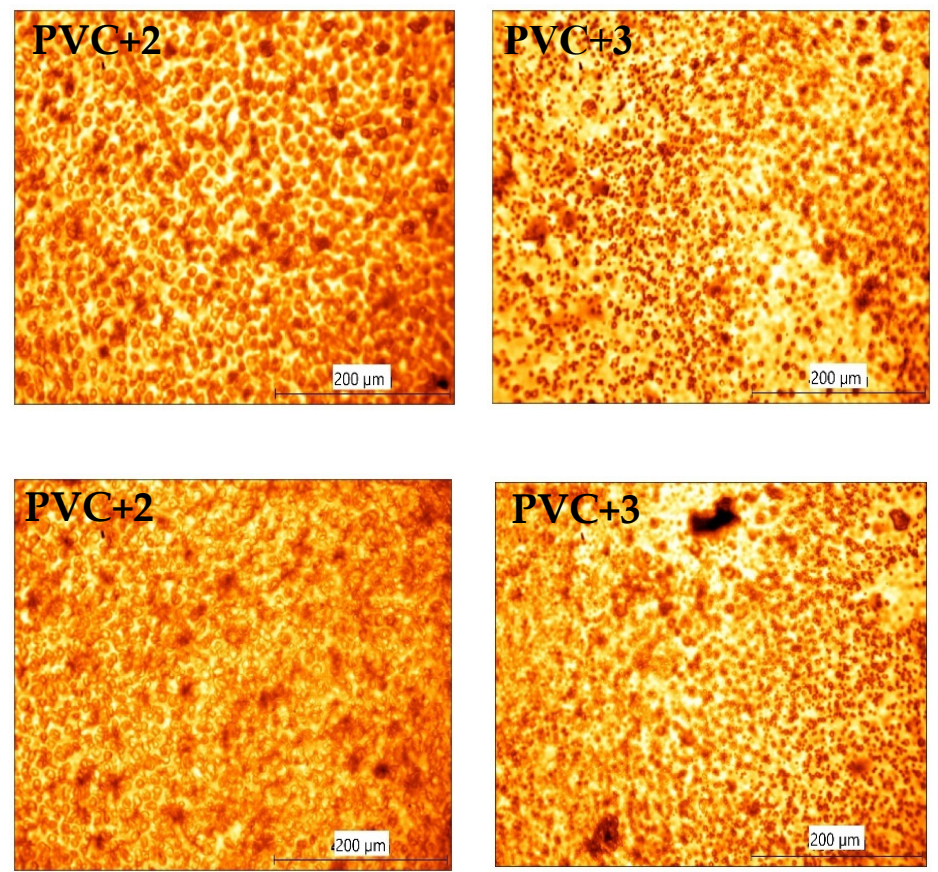

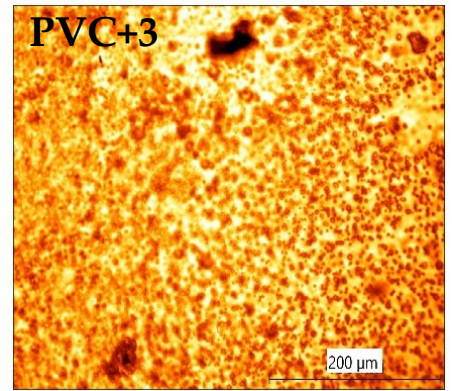

Figure 9. PVC surface microscopic images (a) before exposure to UV light, (b) after exposure to UV light (400× magnification). 


\subsection{Photo-Stabilization Mechanisms}

The di- and tri-organotin(IV) complexes work as photo-stabilizers for PVC films during irradiation. The three organotin complexes were synthesized for reducing PVC photo-degradation and their efficiencies follow the order $\mathbf{1}>\mathbf{2}>\mathbf{3}$. Such additives can stabilize PVC films depending on several mechanisms. Tin is a strong Lewis acid, so it can act as an excellent hydrochloride scavenger (Figure 10). Tin(IV) ion can displace chlorine atom within the polymer backbone by the oxygen atoms of the carboxylate group. Such stabilizers give excellent photo-stabilizing long-term PVC by being used as secondary stabilizers [45].<smiles>[2H][Sb]([2H])(OC(=O)C(C)c1ccc(CC(C)C)cc1)(c1ccccc1)c1ccc(CC(C)C)cc1</smiles>

Figure 10. Organotin complexes act as hydrochloride scavengers.

The complexes could act as peroxide decomposers for reduced photo-degradation of PVC. The photo-oxidation of PVC produces radicals that cause the production of $\mathrm{POOH}$ by reacting with oxygen [46]. Thus, tin complexes can decompose peroxides (for example, hydroperoxides) (Figure 11) [47].

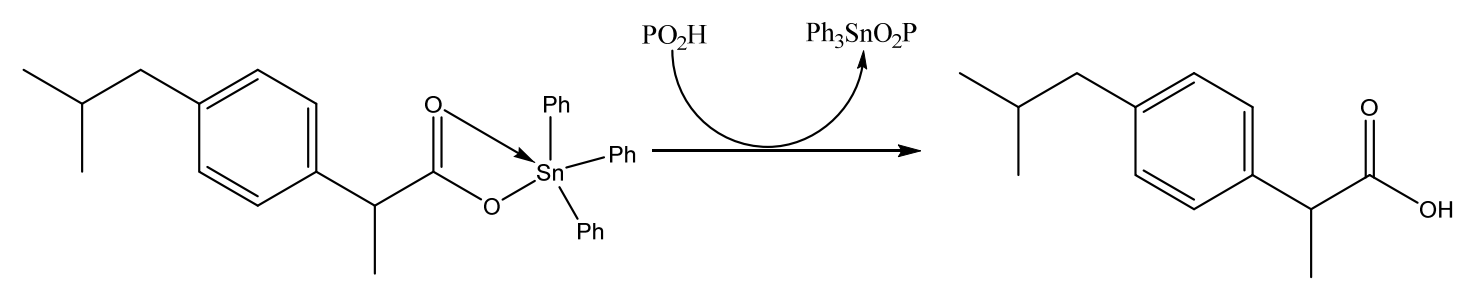

Figure 11. Organotin complexes as peroxide decomposers.

Figure 12 shows the attraction between the complex (photo-stabilizer) and the polymer chain, especially the polarized $\mathrm{C}-\mathrm{Cl}$ bond. This could help to stop the photo-degradation of polymer as these additives act as primary stabilizers by absorbing the UV light from the sun. The attraction between organotin(IV) and PVC can help the conversion energy of the PVC to be excited to an energy level that does not damage the polymer backbone [48].<smiles>CC(C)Cc1ccc(C(C)C(OC(C)(CC(Cl)CC(Cl)CC(C)Cl)CC(Cl)(Cl)CC(Cl)CC(Cl)CC(Cl)CC(C)Cl)[Sn](C)(CC(Cl)(Cl)CC(Cl)CC(C)Cl)c2ccc(CC(C)Cl)cc2)cc1</smiles>

Figure 12. Organotin complexes as primary stabilizers.

This type of stabilizer could prevent PVC's photo-degradation by its role as free radical scavengers as shown in Figure 13. These additives might make a complex with a chromophore in an excited state [49]. Furthermore, these photo-stabilizers can absorb ultra-violet radiation straight away before 
it reaches the PVC and dissipate this energy to lower levels, where it does not harm the chemical structure of the polymer chains due to the photo-stabilizer conjugation system that absorbs the UV [50].<smiles>CC(C)Cc1ccc(C(C)C(=O)O[Sb](c2ccccc2)(c2ccccc2)(c2ccccc2)c2ccccc2)cc1</smiles>

Figure 13. Photo-stabilizers act as radical scavengers.

\section{Conclusions}

Three Organotin complexes, numbered 1-3, were synthesized from the reaction of di- and tri-organotin chlorides and Ibuprofen and used as photo-stabilizers for the PVC. These additives showed their efficiency to decrease the photo-degradation of PVC films by using various analyzing methods. These methods showed a significant reduction in the PVC films' photo-degradation and monitored the certain functional groups' growth of carbonyl $\left(\mathrm{I}_{\mathrm{C}=\mathrm{O}}\right)$ and polyene $\left(\mathrm{I}_{\mathrm{C}=\mathrm{C}}\right)$ upon the time of irradiation $(300 \mathrm{~h})$, percentage of weight loss, and changes on the surface of PVC films in the presence and absence of additives. Organotin(IV) complexes stabilize the PVC films by different mechanisms, such as $\mathrm{HCl}$ scavenger, primary stabilizers, and peroxide decomposers. The photo-stabilization impact on PVC followed the order of: $\mathbf{1}>\mathbf{2}>\mathbf{3}>$ PVC (blank). The $\mathrm{Ph}_{3} \mathrm{SnL}$ complex was the most effective complex as a photo-stabilizer for PVC films according to several mechanisms.

Supplementary Materials: The following are available online at http://www.mdpi.com/2571-9637/3/4/39/s1, Figure S1: ${ }^{119} \mathrm{Sn}$ NMR spectrum for complex 1. Figure S2: ${ }^{119} \mathrm{Sn}$ NMR spectrum for complex 2. Figure S3: ${ }^{119} \mathrm{Sn}$ NMR spectrum for complex 3. Figure S4: ${ }^{1} \mathrm{H}$ NMR spectrum for Ibuprofen. Figure S5: ${ }^{1} \mathrm{H}$ NMR spectrum for complex 1. Figure S6: ${ }^{1} \mathrm{H}$ NMR spectrum for complex 2. Figure S7: ${ }^{1} \mathrm{H}$ NMR spectrum for complex 3. Figure S8: FTIR spectrum for Ibuprofen. Figure S9: FTIR spectrum for complex 1. Figure S10: FTIR spectrum for complex 2. Figure S11: FTIR spectrum for complex 3.

Author Contributions: B.W. has conducted practical work and tests. E.Y. has supervised the work, led the team, and suggested the idea of the research. M.H.A.-M. and A.M. helped in analyzing the results. D.S.A., M.K., and A.H.J. helped in writing, revising, and editing the manuscript. All authors have read and agreed to the published version of the manuscript.

Funding: This research received no external funding.

Acknowledgments: The authors like to acknowledge the Department of Chemistry/College of Science at Al-Nahrain University for partially supporting this work.

Conflicts of Interest: The authors declare no conflict of interest.

\section{References}

1. Olushola Sunday, A.; Abdullahi Alafara, B.; Godwin Oladele, O. Toxicity and speciation analysis of organotin compounds. Chem. Spec. Bioavailab. 2012, 24, 216-226. [CrossRef]

2. Pellerito, L.; Nagy, L. Organotin (IV) ${ }^{\mathrm{n}+}$ complexes formed with biologically active ligands: Equilibrium and structural studies, and some biological aspects. Coord. Chem. Rev. 2002, 224, 111-150. [CrossRef]

3. Marzorati, S.; Verotta, L.; Trasatti, S.P. Green corrosion inhibitors from natural sources and biomass wastes. Molecules 2019, 24, 48. [CrossRef] [PubMed]

4. Umoren, S.A.; Solomon, M.M. Recent developments on the use of polymers as corrosion inhibitors-A review. Open Mater. Sci. J. 2014, 8, 39-54. [CrossRef]

5. Ahmed, A.A.; Al-Mashhadani, M.H.; Hashim, H.; Ahmed, D.S.; Yousif, E. Morphological, Color Impact and Spectroscopic Studies of New Schiff Base Derived from 1,2,4-Triazole Ring. Prog. Color Colorants Coat. 2021, 14, 27-34.

6. Makhdoomi, A.; Ahamed, M.B.; Deshmukh, K.; Faisal, M. Electromagnetic interference shielding properties of polyvinylchloride (PVC), barium titanate $\left(\mathrm{BaTiO}_{3}\right)$ and nickel oxide $(\mathrm{NiO})$ based nanocomposites. Polym. Test. 2019, 77, 105925. [CrossRef] 
7. Taha, T.A.; Azab, A.A. Thermal, optical, and dielectric investigations of $\mathrm{PVC} / \mathrm{La}_{0.95} \mathrm{Bi}_{0.05} \mathrm{FeO}_{3}$ nanocomposites. J. Mol. Struct. 2019, 1178, 39-44. [CrossRef]

8. Elashmawi, I.S.; Hakeem, N.A.; Marei, L.K.; Hanna, F.F. Structure and performance of ZnO/PVC nanocomposites. Phys. B Phys. Condens. Matter. 2010, 405, 4163-4169. [CrossRef]

9. Allsopp, M.W.; Vianello, G. Poly(Vinyl Chloride) in Ullmann's Encyclopedia of Industrial Chemistry; Wiley-VCH: Weinheim, Germany, 2012.

10. Liu, T.; Jiang, P.; Liu, H.; Li, M.; Dong, Y.; Wang, R.; Wang, Y. Performance testing of a green plasticizer based on lactic acid for PVC. Polym. Test. 2017, 61, 205-213. [CrossRef]

11. Geyer, R.; Jambeck, J.R.; Law, K.L. Production, use, and fate of all plastics ever made. Sci. Adv. 2017, 3, e1700782. [CrossRef]

12. Lucki, J.; Rabek, J.F.; Rånby, B.; Qu, B.J.; Sustic, A.; Vogl, O. Surface photografting of polymerizable 2-(2-hydroxyphenyl) 2H-benzotriazoles as ultra-violet stabilizers. Polymer 1990, 31, 1772-1781. [CrossRef]

13. Moraczewski, K.; Stepczyńska, M.; Malinowski, R.; Karasiewicz, T.; Jagodziński, B.; Rytlewski, P. The Effect of Accelerated Aging on Polylactide Containing Plant Extracts. Polymers 2019, 11, 575. [CrossRef]

14. Martins, L.M.; Hazra, S.; da Silva, M.F.C.; Pombeiro, A.J.L. A sulfonated Schiff base dimethyltin (IV) coordination polymer: Synthesis, characterization and application as a catalyst for ultrasound-or microwave-assisted Baeyer-Villiger oxidation under solvent-free conditions. RSC Adv. 2016, 6, 78225-78233. [CrossRef]

15. González-Falcón, E.; Arellano, M.; Sanchez-Peña, M.J.; González-Ortiz, L.J. A Quantitative Spectroscopic Study of the Bleaching Phenomena in Plasticized Formulations Containing PVC Exposed to Outdoor Conditions. Polymers 2019, 11, 1481. [CrossRef]

16. Sabaa, M.W.; Oraby, E.H.; Naby, A.S.A.; Mohamed, R.R. Anthraquinone derivatives as organic stabilizers for rigid poly (vinyl chloride) against photo-degradation. Eur. Polym. J. 2005, 1, 2530-2543. [CrossRef]

17. Bufaroosha, M.; Salih, N.; Hadi, A.G.; Ahmed, D.S.; Al-mashhadani, M.H.; Yousif, E. The Effect of UV Aging on the Structure of PVC in the Presence of Organotin (IV) Compounds. Al-Nahrain J. Sci. 2020, 23, 57-61. [CrossRef]

18. Zhang, X.; Pi, H.; Guo, S. Photostabilizing efficiency of ultraviolet light stabilizers for rigid poly(vinyl chloride) against photo-oxidation. Polym. Eng. Sci. 2013, 53, 378-388. [CrossRef]

19. Huang, Z.; Ding, A.; Guo, H.; Lu, G.; Huang, X. Construction of nontoxic polymeric UV-absorber with great resistance to UV-photoaging. Sci. Rep. 2016, 6, 25508. [CrossRef]

20. Yousif, E.; Bakir, E.; Salimon, J.; Salih, N. Evaluation of Schiff bases of 2,5-dimercapto-1,3,4-thiadiazole as photostabilizer for poly (methyl methacrylate). J. Saudi Chem. Soc. 2012, 16, 279-285. [CrossRef]

21. Liu, H.; Dong, L.; Xie, H.; Wan, L.; Liu, Z.; Xiong, C. Ultraviolet light aging properties of $P V C / C a C O_{3}$ composites. J. Appl. Polym. Sci. 2013, 127, 2749-2756. [CrossRef]

22. Ahmed, D.S.; El-Hiti, G.A.; Hameed, A.S.; Yousif, E.; Ahmed, A. New tetra-Schiff bases as efficient photostabilizers for poly(vinyl chloride). Molecules 2017, 22, 1506. [CrossRef] [PubMed]

23. Mohammed, R.; El-Hiti, G.A.; Ahmed, A.; Yousif, E. Poly (vinyl chloride) doped by 2-(4-isobutylphenyl) propanoate metal complexes: Enhanced resistance to UV irradiation. Arab. J. Sci. Eng. 2017, 42, 4307-4315. [CrossRef]

24. Kadhom, M.; Deng, B. Metal-organic frameworks (MOFs) in water filtration membranes for desalination and other applications. Appl. Mater. Today 2018, 11, 219-230. [CrossRef]

25. Deanin, R.D.; Reynolds, H.H.; Ozcayir, Y. Thermal stabilization of polyvinyl chloride by group II metal laurates $^{1,2}$. J. Appl. Polym. Sci. 1969, 13, 1247-1252. [CrossRef]

26. Chen, X.; Li, C.; Zhang, L.; Xu, S.; Zhou, Q.; Zhu, Y.; Qu, X. Main factors in preparation of antibacterial particles/PVC composite. China Particuology 2004, 2, 226-229. [CrossRef]

27. Cheng, Q.; Li, C.; Pavlinek, V.; Saha, P.; Wang, H. Surface modified antibacterial $\mathrm{TiO}_{2} / \mathrm{Ag}^{+}$nanoparticles: Preparation and properties. Appl. Surf. Sci. 2006, 252, 4154-4160. [CrossRef]

28. Birmingham, J.N. The effect of surface oxidation and titanium dioxide on exterior PVC color retention. J. Vinyl. Addit. Technol. 1995, 1, 84-87. [CrossRef]

29. Beltrán, M.; García, J.C.; Marcilla, A. Infrared spectral changes in PVC and plasticized PVC during gelation and fusion. Eur. Polym. J. 1997, 33, 453-462. [CrossRef]

30. Rabek, J.; Ranby, B. Photodegradation, Photooxidation and Photostabilization of Polymers; John Wiley: New York, NY, USA, 1975. 
31. Yousif, E.; Haddad, R.; Yusop, R.M. Ultra Violet Spectra Studies of Polystyrene Films in Presence of Some Transition Metal Complexes with 4-amino-5-(pyridyl)-4h-1,2,4-triazole-3-thiol. Orient. J. Chem. 2015, 31, 591-596.

32. Yusop, R.; Shalan, N.; Ahmed, A.; Derawi, D.; Al-Amiery, A.; Kadhum, A.; Haddad, R.; Yousif, E. Photochemical and Physical Study of PVC-Amines Polymers. Aust. J. Basic Appl. Sci. 2014, 8, 394-401.

33. Mark, J.E. Physical Properties of Polymers Handbook; Springer: New York, NY, USA, 2007.

34. Mohammed, A.; El-Hiti, G.A.; Yousif, E.; Ahmed, A.A.; Ahmed, D.S.; Alotaibi, M.H. Protection of Poly(Vinyl Chloride) Films against Photodegradation using Various Valsartan Tin Complexes. Polymers 2020, 12, 969. [CrossRef] [PubMed]

35. Kumari, R.; Banerjee, S.; Roy, P.; Nath, M. Organotin (IV) complexes of NSAID, ibuprofen, X-ray structure of Ph3Sn (IBF), binding and cleavage interaction with DNA and in vitro cytotoxic studies of several organotin complexes of drugs. Appl. Organomet. Chem. 2020, 34, e5283. [CrossRef]

36. Refat, M.S.; Mohamed, G.G.; El-Sayed, M.Y.; Killa, H.; Fetooh, H.; Al-Omar, M.A.; Naglah, A.M. Preparation, Spectroscopic, Theoretical Thermodynamic and Antimicrobial Discussions of Zr (IV), Ce (III) and Th (IV) Ibuprofen Drug Complexes. J. Comput. Theor. Nanosci. 2016, 13, 5269-5276. [CrossRef]

37. Shahid, K.; Ali, S.; Shahzadi, S.; Badshah, A.; Khan, K.M.; Maharvi, G.M. Organotin(IV) complexes of aniline derivatives. I. Synthesis, spectral and antibacterial studies of di- and triorganotin(IV) derivatives of 4-bromomaleanilic acid. Synth. React. Inorg. Met-Org. Chem. 2003, 33, 1221-1235. [CrossRef]

38. Andrady, A.; Searle, N. Photodegradation of rigid PVC formulations. II. Spectral sensitivity to light-induced yellowing by polychromatic light. J. Appl. Polym. Sci. 1989, 37, 2789-2802.

39. Rasheed, R.; Mansoor, H.; Yousif, E.; Hameed, A.; Farina, Y.; Graisa, A. Photostabilizing of PVC films by 2-(aryl)-5-[4-(aryloxy)-phenyl]-1,3,4-oxadiazole compounds. Eur. J. Res. 2009, 30, 464-477.

40. Allcock, H.; Lampe, F.; Mark, J.E. Contemporary Polymer Chemistry, 3rd ed.; Pearson Prentice-Hall: Upper Saddle River, NJ, USA, 2003.

41. Blanco Jerez, L.M.; Rangel Oyervides, L.D.; Gómez, A.; Jiménez-Pérez, V.M.; Muñoz-Flores, B.M. Electrochemical metallization with Sn of (E)-4-((4-nitrobenzylidene)amino)phenol in non-aqueous media: Characterization and biological activity of the organotin compound. Int. J. Electrochem. Sci. 2016, 11, 45-53.

42. Farjamia, M.; Vatanpourb, V.; Moghadassi, A. Fabrication of a new emulsion polyvinyl chloride (EPVC) nanocomposite ultrafiltration membrane modified by para-hydroxybenzoate alumoxane (PHBA) additive to improve permeability and antifouling performance. Chem. Eng. Res. Des. 2020, 153, 8-20. [CrossRef]

43. Alotaibi, M.H.; El-Hiti, G.A.; Yousif, E.; Ahmed, D.S.; Hashim, H.; Hameed, A.S.; Ahmed, A. Evaluation of the use of polyphosphates as photostabilizers and in the formation of ball-like polystyrene materials. $J$. Polym. Res. 2019, 26, 161.

44. Shi, W.; Zhang, J.; Shi, X.-M.; Jiang, G.-D. Different photodegradation processes of PVC with different average degrees of polymerization. J. Appl. Polym. Sci. 2008, 107, 528-540. [CrossRef]

45. Folarin, O.M.; Sadiku, E.R. Thermal stabilizers for poly(vinyl chloride): A review. Int. J. Phys. Sci. 2011, 6, 4323-4330.

46. Pospíšil, J.; Klemchuk, P.P. Oxidation Inhibition in Organic Materials; CRC Press: Boca Raton, FL, USA, 1989; Volume 1, pp. 48-49.

47. Jellinek, H. Aspects of Degradation and Stabilization of Polyolefines; Elsevier: Amsterdam, The Netherlands, 1978.

48. Li, D.; Zhou, M.; Xie, L.; Yu, X.; Yu, Y.; Ai, H.; Tang, S. Synergism of pentaerythritol-zinc with $\beta$-diketone and calcium stearate in poly(vinyl chloride) thermal stability. Polym. J. 2013, 45, 775-782.

49. Shyichuk, A.V.; White, J.R. Analysis of chain-scission and crosslinking rates on the photooxidation of polystyrene. J. Appl. Polym. Sci. 2000, 77, 3015-3023.

50. Balakit, A.A.; Ahmed, A.; El-Hiti, G.A.; Smith, K.; Yousif, E. Synthesis of new thiophene derivatives and their use as photostabilizers for rigid poly(vinyl chloride). Int. J. Polym. Sci. 2015, 2015, 510390.

(C) 2020 by the authors. Licensee MDPI, Basel, Switzerland. This article is an open access article distributed under the terms and conditions of the Creative Commons Attribution (CC BY) license (http://creativecommons.org/licenses/by/4.0/). 